\title{
Corela
}

Cognition, représentation, langage

10-1 | 2012

Vol. $10, \mathrm{n}^{\circ} 1$

\section{The viewpoint of the preposition over}

\section{Emmanuelle Roussel}

\section{OpenEdition}

\section{Journals}

Édition électronique

URL : http://journals.openedition.org/corela/2683

DOI : $10.4000 /$ corela.2683

ISSN : 1638-573X

\section{Éditeur}

Cercle linguistique du Centre et de l'Ouest - CerLICO

\section{Référence électronique}

Emmanuelle Roussel, «The viewpoint of the preposition over », Corela [En ligne], 10-1 | 2012, mis en ligne le 10 février 2014, consulté le 01 mai 2019. URL : http://journals.openedition.org/corela/2683 ; DOI : 10.4000/corela.2683

Ce document a été généré automatiquement le 1 mai 2019.

\section{(c) (i) (2)(2)}

Corela - cognition, représentation, langage est mis à disposition selon les termes de la licence Creative Commons Attribution - Pas d'Utilisation Commerciale - Partage dans les Mêmes Conditions 4.0 International. 


\section{The viewpoint of the preposition}

\section{over}

\section{Emmanuelle Roussel}

\section{Introduction}

1 This paper addresses a holistic description of the preposition over ${ }^{1}$, based on the perceptive features of the preposition and on the assumption that language bears some relation with the way human beings experience and encode their environment. The study develops the work on the construction of the spatial limit presented at the $51^{\text {st }}$ SAES Annual Conference held in Lille in May 2010.

2 We have attempted to show that this notion of "limit" was borne out of the observer's perceptive reckoning, thus resting upon cerebral and physical properties, i.e. respectively related to the sense of sight, and to the motion of the observer and of objects in space

The perception in question relies upon the receptive system of the sight organs (given that our neurons only perceive part of the objects and that the brain must choose between several interpretations - Deane (2005: 253), Dehaene 2012). We would like to use this cognitive factor in order to compare the visual principles we have exposed as regards space with notion and time. As a matter of fact, those are the other two main semantic fields to which the preposition also applies.

4 We believe that it is important to take non-strictly linguistic elements into account if one wants to understand linguistic facts and, following Bourguigon (2008), we have adopted an interdisciplinary point of view:

“A l'instar de nombreuses critiques, le présent texte en privilégiera notamment une lecture inverse, et proposera que la diversité linguistique n'est somme toute que le reflet de la richesse conceptuelle avec laquelle l'homme est capable d'appréhender son milieu. En m'appuyant sur de récents arguments issus de faits aujourd'hui reconnus dans les sciences cognitives, je préciserai pour ma part que cette même richesse pourrait dans les faits constituer la base cognitive sur laquelle les langues se seraient 
développées. [...] Enfin, dans la mesure où ma réflexion ne saurait résolument trouver de frontière entre les disciplines, j'encadrerai la présente discussion dans l'esprit des récentes questions soulevées par les sciences cognitives dans l'histoire du langage et de l'humanité ${ }^{\prime}$ ".

\section{Perception, cognition and the preposition over}

Accordingly, our aim is to investigate further the matter of perceptive reckoning so as to confirm its relevance to the notional and "temporal" values of the preposition, which can be found in our corpus. Let us first underline that perceptive reckoning means that time and space are determined according to two main factors, namely the observer and the laws of physical motion. Linguistically speaking, this entails a cause-effect relationship on the pragmatic level, and on the temporal scale, it entails subjective rather than objective duration.

In that case, perception is a bio-cognitive factor at the crossroads between the syntax and semantics of over. This approach is quite original in so far as the study of perception has mainly focused on verb units whose semantic field is compatible with the sensory domain. A subject, being the source of a perceptive intention, or not, perceives an object of perception, "qui est de nature visuelle. Le sujet perçoit quelque chose par le sens de la vue. $^{3}$ " (A. Grezka 2008, 258) Our study of over suggests that the preposition as a grammatical item partakes of such a visual principle without explicitly referring to any organ of perception. As such, the perceptive properties of B then pertain to various formal, semantic, physical and cognitive criteria.

Consequently we posit that, by using over as a spatial preposition, language does retain the trace of ego's relation with the surroundings, however "inaccurate" neural processing may be. Therefore, the utterances produced are independent neither of ego as a speaker nor of the physical world, both being connected by the sense of sight and motion.

These two elements are ones that linguists seldom take into account when dealing with the spatial values of the preposition over. Most papers are based on objects or space but neglect the physical properties of said objects or space. Ego's part as an observer is likewise of secondary importance, and over is a mere syntactic connector (Söderlind 1960: 304), which has discrete properties (Ašić 2008), or is the codification of an operation of a given relative location in A. Culioli's Théorie des Opérations Enonciatives framework (Gilbert 2006). The depicted spatial relations seem to exist in themselves or else, for the cognitive linguists, to construct structures based on mental schemes or semantic networks existing in the speaker's mind (Lakoff \& Johnson 1980, Lakoff 1987, Brugman 1988, Langacker 1991, Jackendoff 1991, Talmy 2000). Said structures can also be based on inference principles (Sandra \& Rice 1995, Rice 1996, Tyler \& Evans 2001, 2003). Thus the preposition gets endowed with geometrical patterns such as verticality, position or trajectory (Brugman 1988, Lakoff 1987, Bisiach \& al. 1985, Vandeloise 1990, Paillard 1991, Kreitzer 1997, Tyler \& Evans 2001, 2003), which are then transferred to time (Rice, Sandra, Vanrespaille 1999) and / or notional values ${ }^{4}$. Accordingly, the preposition is said to carry various meanings such as covering, spanning, and superiority, be it numeral or hierarchic (Quirk \& al. 1995, Bourcier 1981, Pottier 1992, Vandeloise 1986 and 2001, Lapaire 1994, Lakoff \& Johnson 1980, Tyler \& Evans 2003, 16, Ašić 2008.). 
Only Dewell 1994, Kreitzer (1997) and Deane (2005) mention the visual factor that makes the creation of a new semantic value of over possible for R. Dewell (1994, 353 and 351) and Kreitzer (1997: 297, 303, 310, 312-313). On the other hand, Deane (2005: 244) connects the polysemy of the preposition with human beings' visual and motor neurological properties, which, according to him, distort the representation of spatial significance (2005: 245). The point of view is expressly said to concern static spatial relations only (2005: 253); however, P. Deane posits the presence of an observer. But in accordance with Einstein's (1916) general theory of relativity, the aforesaid presence of an observer makes absolute stability difficult to obtain. Actually, the physical phenomenon of the rotation of the Earth leads to the motion of each and every entity (be it an object or an observer), notwithstanding that the observer is unaware of the phenomenon. It is a physical fact that cannot simply be disregarded. Consequently, objects do move in space. As soon as the relationships between these objects are observed, they are ipso facto filtered by the system of reference of the observer whose perception, in turn, alters the initial data. Indeed, general relativity postulates that mobility is not an absolute ${ }^{5}$ but a relative concept and that it only exists in relation to something else. Therefore, an object that is observed only exists in relation to the observer (that is to say, from the spatial coordinates of the mobile observer). Thus, the initial spatial coordinates of that object are no longer significant.

Such are the bases on which we have analysed our spatial corpus. ${ }^{6}$

\section{Spatial data}

11 To mention spatial data presupposes that, linguistically speaking, they have beforehand been observed by the speaker. Since A, B and ego are mobile, the relationships indicated by the sequences A over B will neither be regular nor similar from one occurrence to the other.

Parallel to this law, the relationships in question will be perceived through the sense of sight, among others ${ }^{7}$, of ego. Now, it is an established fact that the human brain preferentially distinguishes a few characteristic forms (Dehaene 2006: 17) which do naturally exist in the surroundings of the observer, and are outlined by contrast one with another. It is another established fact that the creation of spatial relationships is linked with our body: "C'est par rapport à notre corps que nous situons les objets extérieurs, et les seules relations spatiales de ces objets que nous puissions nous représenter, ce sont leurs relations avec notre corps"8 (Poincaré 1908: 55).

Therefore, from a linguistic viewpoint based on the assumption that language bears some relation with the external world, the question is the extent to which over, when used in spatial contexts, participates in the transmission of these facts.

The referents of A and B seem to carry salient features which the sense of sight could perceive. The geometrical patterns that cognitive linguists ascribe to the semantics of $\mathrm{A}$ and B would therefore be but the result of neural preferences rather than the schematic representation of forms and of relations said to exist between these forms a priori. In other words, these forms do not seem to be selected in relation to their mere existence but to be constructed ad hoc through their being selected by the brain, and consequently to be produced by the perceptive act itself. 
In order to reveal the supposed salient features of the referents of $B$ allowing them to be selected in a spatial relation signalled by an A over B sequence, we have conducted their componential analysis ${ }^{9}$ in 196 utterances in which the preposition over refers to space. As a result, recurrent semantic characteristics have been defined. Said characteristics carry the salient features that lead to the selection of these referents so as to convey a spatial relation.

\subsection{Analysis of the referents of $B$}

The utterances in question divide into three classes whose meaning, on first approach corresponds to (i) a position (of A in relation to B) or a gesture (from B towards A), (ii) a distance or (iii) a covering of B by A. The statistics read 21 occurrences for the first class (that is to say $10.71 \%$ ), 34 occurrences for the second class (17.35\%) and 141 occurrences for the third class (71.94\%).

This first categorization uses the analytic criteria selected in the aforesaid studies and is illustrated by the following utterances:

(1) A lamp hung over the door. (Quirk \& al., 1995: 685)

(2) He lives over the hills. (Adamczewski \& Gabilan 1996: 281)

(3) The coffee is spilt all over the table. (Ašić 2008: 260)

(4) They threw a blanket over her shoulders. (Quirk \& al., 1995: 685)

(5) They've travelled all over the world. (OALD 2005: 1079)

Our own utterances belong to a corpus of either written or spoken material taken from four novels and, to a lesser extent, the Internet. Unlike the above, they show that in the first sub-class (position or gesture) the referent of $B$ is animate and relates either to the face or head of the human being or else indirectly names this human being:

(6) An old man was sitting there, slumped in sleep, a hat down over his eyes and a fishing bag on his knee. (Kent 2005: 368)

(7) 'Now will you tell me, master, or am I going to have to hold a pillow over your face until you cooperate?' (Laurie 2004: 67)

When the utterance follows the V over NP pattern, the gesture or position denoted by the sequence names the result of an action; the verb phrase refers to an action (close his fingers, hit) or to a movement, mainly horizontal, of the body or of a body part:

(8) ... and ran a cloth over the marble. (C. Kent 2005, 81)

20 As for the referent of A, it either is human animate (fingers, voice) or relates to a thing belonging to the real world. In this first kind of occurrences denoting spatial positions, the referents of $\mathrm{A}$ and $\mathrm{B}$ share the property of referring to body parts, whether directly or indirectly.

21 The occurrences belonging to the second sub-class (distance) deal more specifically with the limit denoted by the referent of $\mathrm{B}^{10}$. This limitation is either a physical limit (tin, house) or corresponds to the horizon. In the first case the limit can be seen since it is concrete; in the second it corresponds exactly to the limitation of view. Both types of reference to distance share the visibility factor that is typical of what is perceptible to the eye. 
then noteworthy that the verbs used in these two groups of utterances denote an activity (travel, chase, sway, ...), namely an unbounded process as regards lexical aspect which notably applies to the occurrences where the end point is not explicitly mentioned, as in (5) They've travelled all over the world. The status of the end limit seems to be what is at stake ${ }^{11}$.

Finally, in the third sub-class (position or passage from one side of an obstacle to the other), the occurrences naming a position are less numerous than those naming a passage (28 to 98$)$ :

(9) She ain't built on Brenda's lines any more but she's not doing so bad for nearly forty herself, and there's the clobber, red leather jacket over a black lace top, for a start. (G. Swift 1997, 7)

(10) There's the sign dangling over his head: NIL BY MOUTH. (G. Swift 1997, 36)

(11) But the appearance of a waiter in the doorway with a napkin over his arm, gave her an access of determination ... (A. Brookner 1993, 30)

(12) If the chair should slip its moorings, it would almost certainly go over the edge -; and there was a thirty-foot drop. (BNC, BMU 797)

In the $\mathrm{V}$ over NP pattern, the verb units are verbs of accomplishment that denote a bounded process including the examples that refer to a position or light contact. This contradicts the argument according to which the prevailing meaning of the preposition over is the expression of a covering movement of a thing, a body, an object or an obstacle:

(13) She passed a hand over her forehead, smelled the girl on her. (Kent 2005: 263)

As a result, the dynamic meaning of the utterances is borne by the verb that names a movement.

As for the referent of B, it either names a thing (deck, table, umbrella, bed, box, stones, roof, hills, chair, windows, edge, wall, back of the upright chair) or metonymically refers to a human animate by means of the mention of the body or a part of the body. In this latter case, the part of the body in question is most often the upper part (body, hair, head, forehead, eyes, face, neck, mouth, ears, fingers, ankles, feet) and typically the shoulder-s (27 occurrences ${ }^{12}$ ). What is even more meaningful is that 29 utterances (out of the 34 of this group in which the referent of $B$ belongs to the upper part of the body) rely on the sense of sight. B is either clearly visible or partially and even totally hidden.

Significantly, all the referents of B share recurrent semantic features.

\subsection{Analysis of the semantic features of the referents of $B$}

The analysis of the semantic features that we have carried out rests on the selection of distinctive semantic features regarding the spatial issue we have been concerned with, as well as the salient factors we have been seeking. We could have chosen other features, such as colour, size, density, substance, smell and so on, but they may well have been less convincing in so far as they do not deal with the characteristic forms that the human brain discriminates ("The system encoding space (...) encodes information about the shape of the environment, and ignores featural information such as colours..." - Izard et al. 2011: 320). The analysis deals with the referents of B that are inanimate (22 lexical 
items), human animate (16 lexical items) and those that name body parts (16 lexical items).

We have retained the 28 following features: /THIN/, /THICK/, /FLAT/, /HORIZONTAL/, / VERTICAL/, /POINT/, /SURFACE/, /VOLUME/, /LINE/, /STRAIGHT LINE/, /SIDE/, / ANGLE/, /POINT ${ }^{13}$ /, / EDGE ${ }^{14}$ /, /ROUNDNESS/, /ROUND/, /HOLE/, /CAVITY/, /EMPTY/, / FULL/, /HARD/, /SOFT/, /INANIMATE/, /HUMAN ANIMATE/, /OBJET/, /ELEMENT ${ }^{15}$ /, / MOBILE/, /IMMOBILE/. At this point we would underline that these are semantic features and do not refer to the real world.

a. In the first case, the comparison of these 28 features with the inanimate referents of $B$ (in A over B sequences) shows that they bear the following components of meaning: /+ INANIMATE/16, /+ HORIZONTAL/, /+ MOBILE/, /+ IMMOBILE/, /+ FLAT SURFACE/, /+ THICK SURFACE/, /+ LINES/, /+ ANGLES/, /+ SIDES/.

$\mathrm{b}$. In the second case, the features present in the human animate referents of $\mathrm{B}$ are: /+ VERTICAL/, /+MOBILE/, /+IMMOBILE/, /+THICK SURFACE/, /+SOLID SURFACE/, /+HARD SURFACE/, /+SOFT SURFACE/, /+ SIDES/, /+ ROUNDED ANGLES/.

One notices at once that both kinds of referents share the following features: /SURFACE/, /THICKNESS/, /SIDES/ and /ANGLES/.

c. In the last case in which the referents name body parts, 14 lexical items bear the feature /BODY PART/ and 12 others bear the feature /UPPER (BODY) PART/.

Thus, it appears that in A over B sequences the preposition is used when B meets certain semantic criteria among which /SURFACE/, /THICK/, /SIDES/, /ANGLE/, /MOBILE/. Three of these criteria (/SURFACE/, /SIDES/, /ANGLES/) happen to correspond to the forms that the brain distinguishes first and foremost. What is all the more significant is that 29 out of 34 utterances involving body parts include the criterion of visibility: perception seems to be what enables the interaction between the brain and the referent of B. Moreover, the referents of B for these upper body parts, notably the shoulders, resort to motion which can apply to the body, but also to sight or voice:

(14) Toto leaned over his shoulder, ran his finger down the scrolled pages until he reached first one highlighted name, than another. (Kent 2005: 246)

(15) She had turned her matted head convulsively this way and that, looking over her shoulder as they left the village and peering down each slope as they wound down to Levanto. (Kent 2005: 263)

(16) 'Turn off the light', he said over his shoulder in a low, calm, voice. 'It's very annoying.' (Heller 1955: 389)

(17) Her square face darkened with hostility, she shook a tea towel at Ania and shouted over her shoulder, back into the house. (Kent 2005: 207)

Consequently, the perception involved turns out to be a dynamic perception in so far as it evolves in context. As such we could talk about "perceptive reckoning" which, as mentioned above, is well rendered by the internal aspect of the verbs used in the $\mathrm{V}$ over SN sequences. These verb units (hover, hold, stand, came, pass, run, fall, slid, travel, step, bend, lean, put) admittedly illustrate the classical values of position, trajectory, spanning or covering. Nevertheless, they also name notions, which can be expressed in aspectual terms, namely accomplishment (spanning), achievement (covering, position) or activity (trajectory). According to us, these notions are notions of aspect rather than notions of space.

The spatial relations signified by over are really of the egocentric type, in Deane's words (2005: 247); that is to say that they are constructed with regard to the body, and their 
primary reference frames are the line of vision, lateral or frontal orientation of the chest and motion of the body. Once this reference to the body is made, it is underpinned by a perceptive criterion, which, through ego's observation, makes spatial relations dynamic. Therefore, the previous analyses of semantic features show that the visual criterion is an invariant distinguishing feature, which would explain why the referents of $B$ have the form(s) that they are given.

These are the bases on which we are now going to attempt to refine the analysis of the perceptive criterion as one of the characteristics of the preposition over. For this purpose we are going to present our study of two other corpora, respectively a notional corpus and a temporal corpus.

If over initially applies to space, then its notional and temporal meanings cannot but be secondary. If this analysis is correct, it follows that notional values can be understood as being the linguistic counterpart of position:

(18) The following picture, however, like the preceding one on PIE nonmaterial culture, is presented with all due caution, and it should be kept in mind that controversy hovers over practically every claim (Fortson 2004: 40)

As for its time and excess values, they could be equated with horizontal distance (19) and the overstepping of a limit potentially perceived as an obstacle (20):

(19) The range has been well documented by researchers such as Hellgard Raugh, a psychologist at the University of Potsdam in Germany, who has observed the progress of more than 30 Down syndrome children over several years. (Moeller 2007: 45)

(20) The average age is thirty-nine, but in some areas, such as East Anglia, over half of the labour force is over the age of forty-five (BNC, FPR 33)

This suggests that the various meanings of over can be accounted for by considering the hypothesis of an abstract shift from an initially concrete perspective. Our aim is to show that this is not the case.

\section{Notional data}

37 utterances out of the 297 compiled in our notional (or thematic) corpus, that is $12 \%$, illustrate the use of B as a context specifier. Their study shows that they belong to the semantic fields of guilt, disagreement, emotion, conflict, controversy, divergence, questioning, uncertainty, rebellion, ideological debate, confrontation, quarrel,...:

(21) Informing the ADHD Debate. The latest neurological research has injected much needed objectivity into the disagreement over how best to treat children with attention-deficit disorders. (Rothenberger \& Banaschewski 2007: 36)

(22) When the rain stopped we heard the crowd cheering for the three ten, the big race, the strange noise of people getting het-up over a bunch of horses. And afterwards that became our regular spot, Epsom Downs, every Thursday, for fourteen weeks, racing or no racing. (Swift 1997: 175)

(23) Toto was talking into his radio still; he was trying to persuade them at Genova to scramble the helicopter of the Polizia dello Stato; it would be humiliating to beg one from the carabinieri, not to mention the fight over whose case it was going to be. (Kent 2005: 293) 
(24) The first major demonstration of this was in 1983, in the controversy over the abortion amendment. (BNC, A07 1014)

(25) The reconstruction of names for plants is more problematic than for animals. Very few plant names in the western IE languages have cognates in the eastern languages, a fact that has occasioned much debate over how many terms to reconstruct for PIE. (Fortson 2004: 44)

(23) Toto (...) not to mention the fight over whose case it was going to be.

(26) LEVEL 42 have a new record deal with RCA, having settled out of court with their old label Polydor following a dispute over the band's next album.

(BNC, CAD 9)

In addition, the semantic role of this first term (the fight and following a dispute respectively) appears to be the role of the effect in the relation set up between $A$ and $\mathrm{B}$ : fight and dispute (A) name the result of the cause expressed by case and album in $\mathrm{B}$. The process is illustrated by (26a) or (24a) which gloss (26) and (24):

(26a) The band's next album led to / resulted in a dispute.

(24a) The abortion amendment caused controversy.

One notes that the cause (B) cannot be mentioned first, as could be expected in a causeeffect relationship. Indeed, dispute becomes the theme of the record in (26b), which is not the case in (26):

(26b) ... the band's next album over a dispute.

(26) LEVEL 42 (...) settled out of court with their old label Polydor following a dispute over the band's next album.

Therefore, A does denote the result of the relation expressed by A over B. So, syntax does not reflect the cause-effect order pre-existing in the real world. Syntax does not reflect the initial stage where the logical relation is intellectually processed, it encodes a secondary stage. Indeed, establishing a link between A and B is a requisite for measuring which of either of these terms comes first. To put the effect before the cause in the linear chain amounts to illustrating what could be called a phenomenon of retro-action in three stages on the speech level. As far as the observer is concerned, the first stage consists in establishing a link between necessarily different "objects" of the discussion; the second consists in appraising the parts played by these objects in the discussion, and the third in concluding on the two previous stages:

1. first movement: from subject 1 to subject 2 (of the debate)

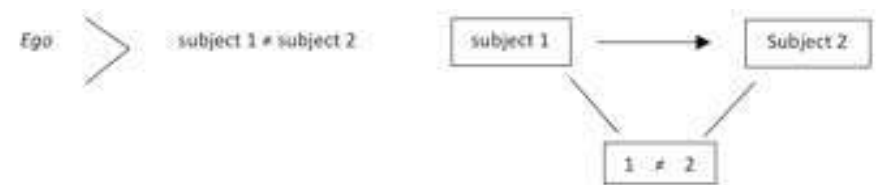

43 Then 
; the substantive is used with verbs such as arouse, cause, create, provoke, spark or stir which denote the starting point of the process. It is likewise compatible with the present perfect or with prepositional phrases denoting duration. Take the following utterances for instance:

(32) Even now, the controversy was not resolved. (BNC, EF4 358)

(33) However, the research findings have not always been consistent and there has been controversy over their significance. (BNC, J14 1420)

(34) After five years of controversy it is about to be laid to rest. (BNC, ABK 2965)

(35) The result was controversy between Vienna and St Petersburg which 
dragged on for two decades. (BNC, HY5 359)

(36) During the 20th century, anorexia nervosa was ascribed a psychological cause by other physicians (eg, Charcot, Dubois, Fenwick, Janet) but then became confused with pituitary insufficiency in 1914 by Simmonds, leading to a controversy that persisted for 30 years. (BNC, HWW 694)

Interestingly enough, (37) is a good example of both aspectual movements:

(37) The agreement, which was announced by the Department of Health, brings to an end six years of controversy over the future of the Adelaide. (BNC, HJ4 8890)

52 It follows that the aspectual factor is significant both in the notional uses of the preposition over and in those dealing with space. The notional limit is questionable in the examples (32) to (36). Similarly, the spatial limitation denoted by over can be vague when it is expressed by noun phrases such as country, area or hills and dales (in that case, the internal aspect of the verb used is one of activity). The preposition is found in contexts favouring the expression of the involvement of the speaker who "assesses" the limit, whether notional or spatial, denoted by B. Accordingly, each utterance illustrates a link established with the observer and/or the speaker, namely ego.

It has been established that the sequences that are classified as notional occurrences of the preposition over are characterized by the fact that they assert the effect before the cause. As such, they denote the result of a working of the mind that consists in (i) deconstructing the initial nature of the relation between $\mathrm{B}$ and $\mathrm{A}^{21}$, (ii) analysing that relation, then (iii) reconstructing it on new bases. Since each extralinguistic reference is specific to A and B in each sequence, and since A and B are independent of each other a priori, this mental process can only be carried out by ego the observer common to all occurrences.

54 As a matter of fact, even though a cause is necessary to obtain an effect, the cause expressed by B can lead to more than one effect. In addition, it is noteworthy that the cause is not definitive. Accordingly, A over B underscores that the effect (A), and no other, is uniquely triggered by the cause (B) at the very moment of speaking. The effect that is asserted about the cause equally depends on this cause. It follows that the entailment relation that exists between $B$ and $A$ is neither primary nor natural. It is in fact produced by ego, just as the spatial relations are established according to ego. Therefore, this production has to be encoded, notably by means of the reversal of the linear ordering of $\mathrm{B}$ and $\mathrm{A}$.

Whether the context in which the preposition over appears has to do with space or any particular notion, A over B shows the evidence of a specific value emerging between A and $\mathrm{B}$. That value turns out to be filtered by the visual or analytical perception of ego to find linguistic expression in various aspectual contrasts conveyed either by the verb items or the noun phrases.

56 At this stage, it is worth pointing out, too, that exactly the same phenomenon can be observed when A over B has time reference.

\section{Time data}

Our time corpus consists of 46 utterances $(15 \%)$ in which we have studied the referents of $A$ and of $B$. The latter have specific syntactic and semantic characteristics. The referent of B can be expressed by a variety of terms, such as several years, the weekend, fifteen 
years, the years (9 occurrences), twenty years (ago), time (3 occurrences), a period of time, a week's time, the next decade, the past few decades, a 17-year period and even the second quarter of fiscal year 1991. As for the referent of A, which is either NP or V, it includes constituents such as the progress, progressively, continually, develop, gain, arise, change, become, grow into, grow by. The verbal units are (i) in the simple present or the present progressive, (ii) in the preterite or (iii) in the present or past perfect, and the verbal happenings that they denote are in process. Those verbal items often are resulting copular verbs. The noun phrases name a change in something. The aspectual forms are used to present a particular event from the speaker's viewpoint. The various phrases accompanying the perfects denote an action that extends into the moment of speaking or assess the impact that a past event bears on the present moment. The progressive takes on an appreciative meaning, which is highlighted by the use of adverbials such as continually. These contextual elements all signal duration ${ }^{22}$ :

(38) Elvira had first met Luke and Annabel at the gallery, of course, something like eight, nine years before, and she had not warmed to them over time; rather the opposite. (Kent 2005: 135)

(39) These songs are continually changing over the years. (BNC, ABC 302)

(40) Anthony Stewart comes to trial in just over a week's time. (BNC, FP7 1683)

(41) It was the great fire of London in 1666 which gave him his opening, however, and he became a prominent figure in the rebuilding of the city over the next decade. (BNC, GTA 1146)

(42) Many thanks (...) and for your company over the years. (private corpus)

(43) And then the chaos in front of him took shape and Cirri didn't have time to think about Toto any more; this was something else, something terrible had happened here, and the instinct Cirri had developed over twenty years' service told him it wasn't over yet. (Kent 2005: 366)

The duration denoted by the referents of B in our corpus is often conveyed by means of the lexeme year(s). Evidently, it names one of the basic units making up the common framework reference for extralinguistic time ${ }^{23}$, namely a twelve-month framework. Therefore, the duration denoted by this unit, presented as self-evident, does not seem to require any further specification. Nevertheless, said duration turns out to have to do with ego's involvement. This is true even for (42) where the unit referred to (the years) happens to be redefined by the speaker as corresponding to a specific period as far as he was concerned ( $\mathrm{x}$ times [a year]). It is as if the speaker constructed a new time reference. As such, even though no clear mention of the initial or final limits is made, the time delimitation expressed by the term year in these utterances is never approximate, (42) included. Furthermore, it appears that the lack of precise delimitation is not specific to over. Other prepositions can be used in the same way, even though it must be said that in those cases an element clarifies the time reference:

(44) ... over ten minutes. (5 occurrences in the BNC)

(45) ... in about ten minutes. (16 occurrences)

(46) ... in about a week. (14 occurrences)

(47) ... in about a year. (5 occurrences)

(48) ... for something like a year. (1 occurrence)

Which is not the case for: 
(49) * ... over about / like a year. (0 occurrence in the BNC)

$(50) *$... over about ten minutes ( 0 occurrence)

(51) ? ... over something like a year. (0 occurrence)

But (51a) is possible:

(51a) ... over a year or so.

61 So, when the time reference is approximate, it cannot be mentioned immediately after over but comes after the sequence [over $+\mathrm{SN}$ ]:

(52) * ... over something like years. (0 occurrence)

$(51) * \ldots$ over about years. (0 occurrence ibid.) vs. (51a) : ... over years. (25 occurrences)

$(52) *$... over about the years. (0 occurrence ibid.) vs. (52a) : ... over the years (1962 occurrences)

62 As a result, over seems to have to be closely related to the next constituent [see (49)-(52)], which cannot be in keeping with the preposition signalling time vagueness. The duration denoted by over cannot be characterized by approximation. Its main feature is something else.

Indeed, the preposition cannot locate an event on the time axis, and as such differs from during: "During locates in time" ${ }^{24}$. Conversely, over "indicates the duration of a state or an action up to the present moment ${ }^{25}$ ", as shows the use of the preposition with the present perfect that "has an impact on the present moment ${ }^{26 "}$. Take (53) which is formed with constituents presented as typical of the use of over:

(53) Things have changed a lot over the last ten years. (Persec \& Burgué 1999:

36)

However, even if (53) brings together some of the constituents generally collocating with over, it does not reveal anything regarding the actual characteristics of the duration that it expresses. This is due to two main reasons.

The first reason is that (53) is generic (things), whereas our utterances mainly refer to specific situations. Those situations can be singular or plural. We find noun phrases such as she, Anthony Stewart, your company, the instinct, the rebuilding of the city (city denoting London here), which can be postmodified by an adnominal relative clause introduced by zero: ...Æ Cirri had developed, leading to greater determination of the NP. We also find noun phrases such as these songs where plurality applies to a unique NP, which means that what is referred to is the reiteration of one occurrence or of one class of utterances. Thus, (53) is not representative of the temporal uses of over.

The second reason is that in being used as an illustration of the contrast that is said to exist between tense (during) and duration (over), (53) presents duration as being selfevident. This occurs whenever is in question the end-point ("... up to the present moment") of a process ("the duration of a state or an action") only. Without any clear definition of said concept of "duration", it is as if it were acquired knowledge. And yet the word duration covers various phenomena, according to the way it reads in such and such domain. 
68 As regards time, duration is considered as a stretch of time elapsing between two observed limits: the initial and the final limits (cf. supra). As regards linguistics, and more particularly verbs, duration is the interval existing between the starting and the stopping points of an event (whether this event denotes an activity, an accomplishment or an achievement). Both concepts appear to overlap at first, and this may be the case as an undergoing occurrence spans over a certain amount of time, however short. Yet, the domains pertaining to both concepts are not the only ones involved whenever the observer / speaker communicates about the duration in question.

Following our hypothesis that comprehensive knowledge of language facts requires taking not only strictly linguistic but also bio-cognitive and physical ${ }^{27}$ elements into account, we need to take active interest in the cerebral and physical definitions of duration.

Bio-cognitively speaking, duration is linked to emotions because it depends on the way we experience events. As for emotions, they pertain to episodic memory ${ }^{28}$, the memory system that deals with ego's dated autobiographical events. As a consequence, these events are unique and linked to ego's own history with its specific space and time determination (Roussel 2007b). Therefore, the episodic memory system directly related to duration deals with the way we perceive events.

71 Therefore, the duration of an event fundamentally pertains to the perception that ego gets of that event. More precisely, with the perception of its contents, of the emotional reactions it provokes as well as of the way images are presented (Damazio 2006). Accordingly, (the perception of) duration is subjective.

In physics, duration is also inextricably linked to subjectivity. Time is divided into two sub-notions. The first one is objective time, meaning clock time (that is to say the atomic second ${ }^{29}$ ), and is therefore external to us. On the other hand, the second sub-notion is subjective time and deals with duration, i.e. it depends on the emotions that we experience. The comparison made here with physical properties is not new, in so far as the physical criterion of subjectivity was taken into account by Benveniste (1974: 70), who defined duration as follows: "... the subjective part of physical time. ${ }^{30 \text { " }}$

Before him, Guillaume (1929: 8-9) took perception into account as the origin of the representation of time. He defined it as "operative time" denoting, as regards verbs, a short mental operation ("time-image") during which the mind gives a representation of time: namely "chronogenesis".

74 The subjective character of duration in physics ${ }^{31}$ has among other consequences that of introducing the concept of movement. It has been said that duration determines itself by the existence of two limits, the initial and the final limits. By definition, those limits are distinct from each other. It also turns out that those limits pertain to two distinct moments. In physics, two moments that are experienced as being distinct are necessarily successive. Consequently, the limits of duration are successive, and the duration existing between them results from ego's establishing a relation between the two moments represented by those limits. Since those two moments are perceived as being consecutive, the fact of establishing a relation between them initiates a movement from one to the other $^{32}$. As a result, duration becomes linked to the phased assessment of an interval between two boundaries. This is the reason why it is possible to posit that the duration of an event is fundamentally a matter of perception of that event. Duration and perception are as one. Since perception is a distinctive characteristic of the observer's, every 
perception of duration is intrinsically unique. Therefore, if the expression of duration is the prerogative of over, then the expression of perception, in the true sense, is likewise the prerogative of over.

The utterances (44) to (52) have shown that the duration encoded by over is not approximate. Yet, as is the case for any duration, it is subjective and first and foremost applies to specific situations. Could the preposition over underline the fact that what is most importantly at stake in the utterances is ego's own perception of duration?

Let us re-consider (53) ${ }^{33}$; previously we said that it does not exactly reflect the semantics of the utterances in our corpus, partly because of the fact that the component parts it is made up alter its real impact. As far as we are concerned, (53) is not typical in its denoting a generic event (things - change) as being a means to express quantified duration (the concept of which would be unquestionable), from an objective (ten years) viewpoint. The utterance (53) does not name any type of duration; it implies change (have changed) between two moments, one preceding the other. What is more, if the utterance does underline this change, this is largely due to the grammatical aspect (the present perfect) rendering the internal semantics of the verbal unit (change) explicit. As a matter of fact, we do not think that the change expressed in (53) relies on the quantification of the number of years bearing on the present moment. For us, the duration expressed in (53) does convey personal involvement.

The component parts used in our utterances help define the appraising element in over: it could spring from ego's determining the semantic specification of the utterance ad hoc. If the duration denoted by over is said to be subjective, it is because it does not rest upon any explicit mention of its initial and final limits, contrary to what the concept of duration implies (cf. footnote 23). As has been shown above, B seems to be delimited, yet the utterances do not refer to any precise dating with objective limits. Accordingly, for lack of clear determined limits, duration has to be redefined on bases that are not limitative ones. Here is the utterance (54) in which the co-occurrence of do my best and weekend a priori gives to understand that it will be difficult for the speaker to mark the papers within the time limitation denoted by weekend:

(54) I will do my best to mark the DMs over the weekend so that you have some closure. (private corpus)

The difficulty may be due to the number of papers being too great or the speaker having other things to do. My best denotes an effort on her part so as to conform to the (implicit) limits conveyed by the word weekend ${ }^{34}$. Indeed, the limits in question are implicit since no beginning nor end of the weekend are mentioned, unlike what happens with on in (57, 57a, 57b):

(55) ... over the weekend Æ. (367 occurrences in the BNC)

(56) ... on the weekend $Æ$. (78 occurrences)

(57) ... on the weekend of November 26-27.

(57a) ... on the weekend of September 7-8.

(57b) ... on the weekend 19 and 20 September 1992.

Therefore, over does not seem to require precise dating to be able to refer to the duration denoted by $\mathrm{B}^{35}$.

On the other hand, over has a second effect in (54), according to our bilingual informant who produced the utterance. The preposition gives the weekend a "dynamic 
perspective". The co-occurrence of do my best and weekend "suggests congruent activities during the weekend" that is not "precisely delimited [activities], it depends on the obligations... And I think there were other things to do as well... I think that was what really mattered..." Consequently, it appears that the co-occurrence of do my best and weekend which was presented above as being liable to have at least two meanings, tends to single out the second hypothesis consisting in the obligation to divide the weekend between the marking of the papers and other less studious activities. For our informant, "the weekend is supposed to be a time for rest, leisure". The utterance (54) signals a conflict between the event denoted by the verb item mark and the time framework in which that event is supposed to take place: the weekend. We think that over directly participates in that meaning in so far as, still according to our informant, the preposition "suggests that time is segmented, that is to say ... (in) numerous or undetermined activities". In other words, unlike what she feels for at ${ }^{36}$ or on, "the marking time could not span the whole 48 hours $^{37}$ with over". The prepositions on and over can be syntactically interchanged as will be shown again below, but they differ on the semantic level. Over refers to segmented activities occurring during the time interval denoted by the duration whereas on refers to the same activities spreading out over the interval denoted by the duration. The duration signalled by over is not one and indivisible but corresponds to the sum of several instances of duration spanning a time interval defined by an initial and a final limit. As for the prepositions on and at, they express perfect conformity between the nature of the activities denoted by the event(s) and the limited time interval.

But duration is not supposed to be segmented; it is supposed to be continuous. As such, over does signal a specific meaning of the lexeme "duration" as well as the speaker's comment concerning the altered semantics.

Therefore, as is illustrated by (54), the duration encoded by over is not definitive but builds up in context.

Indeed, it is significant that, unlike other prepositions such as on, at or during which also appear in such sequences [preposition the weekend], over is not uncommon in the sequence [over the weekend] but it is in [over the weekend + of + date or NP]:

(55) ... over the weekend $Æ$. (367 occurrences in the BNC)

(56) ... on the weekend $Æ$. (78 occurrences)

(58) ... during the weekend $Æ$ he died. (BNC, A96 344) (41 occurrences) ${ }^{38}$

(57) ... on the weekend of November 26-27.

(59) ... during the weekend of 10-12 April 1981. (BNC, AS6 270)

(60) ... during the weekend of June 27 and 28. (BNC, CJ6 310)

(61) ... during the weekend of the race. (BNC, BPK 1186)

(62) ... during the weekend of the Windsor fire. (BNC, CBF 8624)

(63) ... during the weekend of de Klerk's visit to Kenya ... (BNC, HL8 44)

The examples (59) to (62) illustrate the fact that a date, or a noun phrase beginning with the preposition of, can clearly postmodify the interval in which the point determined by during is located.

However, if during does locate an event in a time interval, the dates postmodifying the weekend do not give any particular information relative to the exact location of that event determined by during. What they do is determine both limits of the interval: 
(60a) ?? ... during the weekend of June 27 and September 14.

(62a) ?? ... during the weekend of the Eiffel Tower fire.

(64) The locomotive is due to arrive at Bury by road and make its first appearance at a hastily-organised Great Western Weekend over the weekend of November 14-15. (BNC, CKK 18)

(65) A bus link between Welshpool and Shrewsbury was in operation over the weekend of 26th-27th January due to construction work on the A5/A49 Shrewsbury bypass. (BNC, HHK 1269)

(66) A report says Duke Street is to be narrowed at the east of Raby Terrace to one lane over the weekend of March 28 and 29. (BNC, K52 4750)

Yet, the following extracts [(64a), (65a) and (66a)] show that the original utterances do not so much underline the initial and final limits of the specified weekends as they refer to weekends during which exceptional events occurred: [due to - first appearance (64a)] ; [due to a construction (65a)] ; [is to be narrowed (66a)]. The date appears to underline the speaker's assessment of duration, which agrees with the semantics of the preposition that has been defined here: the personal expression of duration.

It has also been shown here that time and duration do not follow the same principle ${ }^{39}$. Accordingly, no temporal semantics would partake in the temporal uses of over.

In positioning itself between two different entities (A over B), rather than taking part in the determination of distinct referents denoted by $\mathrm{A}$ and $\mathrm{B}$, the preposition over might underscore the speaker's active part in the establishment of the relations existing between A and B. It seems to be an unvarying principle consisting in expressing the reckoning inherent in ego's perception of (i) their own relation to their surroundings (space), (ii) a reversed entailment relation (theme) or (iii) specific duration (time).

2 So, the question is whether it is legitimate to define over as an operator locating objects in space or events in time without the intervention of ego. The perceptive reckoning inherent in the different uses of over shows that the (spatial, notional or temporal) limits referred to by the preposition is the responsibility of ego because these limits are created through the observer's active perception. This accounts for the various uses of the preposition belonging with subjectivity, pragmatics or reproachful excess. What is expressed here is not so much excess as too great a hiatus in the perception of two entities.

93 To say that limits are created through perception means that we do not perceive entities as being objectively fixed but rather we perceive them in their relation to ourselves at a given moment in time ${ }^{40}$. This perceptive reckoning seems to result in the utterance ad 
hoc. Consequently, the relations denoted by A over B are valid for ego (or any observer other than ego) at that specific moment only and tell nothing of the relations between $\mathrm{A}$ and $\mathrm{B}$ before and after that moment. If this claim is correct, it follows that the reckoning rendered by the various uses of over analysed above can be interpreted as the movements creating our own space that H. Poincaré mentioned (footnote 9).

Therefore, the preposition not only joins two components syntactically, it seems to "rejoin" them in so far as it underscores the link it establishes between two entities. At the same time, said entities only make sense (for the utterance) owing to their being related (by ego). As a result, the utterance seems to generate as ego's surroundings forms: in stabilizing constituents for a precise situation when those constituents are but "free constituents" the rest of the time.

\section{Conclusion}

Over seems to convey ego's perception and assessment of their surroundings (space) or their concerns (theme, time). Over does not seem to convey various degrees of measures, places, positions, heights, trajectories or comments about the referents of A and B in A over B. The perceptive reckoning operating on the spatial level then appears to be transferred to the expression of a personal comment on the thematic and temporal levels. The judgement in question is critical for a cause-effect relationship (thematic level) or focuses on a duration whose peculiarity, i.e. segmentation, is meaningful (time level). Since ego's space and time coordinates are specific, the question is whether the addressee, who will submit to their own coordinates, will successfully interpret the value assigned to the preposition by ego (see footnotes 35 and 38). This is where context comes in linguistically. Indeed, the attitudinal principle is encoded by various aspectual values that will guide the addressee, and that one finds in telic or atelic verb units, noun phrases denoting completion put on hold, or the numerous time spans (either retrospective or prospective) that are concerned.

Said aspectual properties hardly come as a surprise when one bears in mind that the lexeme aspect comes from the Latin root meaning observer... Consequently, to describe over in terms of viewpoint seems to be the right way of looking at it.

\section{BIBLIOGRAPHIE}

AŠIĆ, T. (2008), “Espace, temps, prépositions”, in Langues et cultures, Vol. 41, Genève-Paris, Librairie Droz.

BELLANGER, B. (2008), “Quelle est la nature du temps? ", in Les 10 plus grandes énigmes de la science , Science \& Vie n 1091, p. 45-63.

BENVENISTE, E. (1974), Problèmes de linguistique générale, II, Collection Tel, Paris, Gallimard, 1991.

BERGSON, H. (1889), Essai sur les données immédiates de la conscience. 
BISIACH, E., CAPITANI, E. PORTA, E. (1985), “Two basic properties of space representation: Evidence from unilateral neglect", in Journal of Neurology, Neurosurgery, and Psychiatry 48, p. 141-144.

BLOOMFIELD, L. (1935), Language, London, Henderson \& Spalding Ltd.

BORODITSKY, L. (2011), "How Languages Construct Time”, in Space, Time and Number in the Brain. Searching for the foundations of mathematical thought, S. Dehaene \& E. Brannon eds, Academic Press, London, Elsevier, p. 333-341.

BOURCIER, G. (1981), L'explication grammaticale anglaise, Paris, Armand Colin.

BOURGUIGNON, N. (2008), “Le langage : une empreinte cognitive”, CORELA - Volume 6 (2008) | Numéro 2, http://corela.revues.org/317.

BRUGMAN, C. (1988) The story of over: Polysemy, semantics and the structure of the lexicon, New York, Garland Press. [(1981) The story of over, Berkeley, CA: UC-Berkeley master's thesis.]

BUSER, P., DEBRU, C. (2011), Le temps, instant et durée. De la philosophie aux neurosciences, Paris, Odile Jacob.

BUZSÁKI, G. (2005), Nature, vol. 436.

DAMAZIO, A. R. (2006), "Remembering When", in A Matter of Time, Scientific American, vol. 16, n¹, www.sciam.com, p. 34-41.

DAVIES, P. (2006), “That Mysterious Flow”, in A Matter of Time, Scientific American, vol. 16, n¹, www.sciam.com, p. 6-11.

DEANE, P.D. (2005), "Multimodal spatial representation: On the semantic unity of over", in Hampe, Beate (ed.), From perception to meaning. Image schemas in cognitive linguistics, Berlin - New York, Mouton de Gruyter, 235-282.

DEHAENE, S. (2006), "Les bases cérébrales d'une acquisition culturelle : la lecture", in L'enfant précoce en marche vers l'adolescence, Actes du Congrès de l'AFEP, Université de Paris-Sorbonne, $\mathrm{p}$. 13-19.

DEHAENE, S. (2012), "Combinaison de contraintes et sélection d'un percept unique", cours du 31 janvier 2012, Collège de France, http://www.college-de-france.fr/site/stanislas-dehaene/.

DESMARAIS, G., NOLIN, P., FORTIN, R., BOISVERT, A., BROCHU, F., VANASSE, C., KIROUAC, G., PEPIN, M. (1997), Mémoire et apprentissage, Rapport de synthèse préliminaire, Hôpital Marie Enfant, Université du Québec à Trois-Rivières, Université Laval, http://membres.lycos.fr/ bouchez.Epmemo.htm.

DEWELL, R.B. (1994), “Over again: image-schema transformations in semantic analysis”, in Cognitive Linguistics, 5(4), p. 351-380

GILBERT, E. (2006), "Remarques autour de quelques prépositions", in Antoine Culioli. Un homme dans le langage. Originalité, diversité, ouverture. Actes du colloque de Cerisy-la-Salle, juin 2005, Paris, Ophrys, p. 285-301.

GREZKA, A. (2009), La polysémie des verbes de perception, Coll. Sémantiques, Paris, L'Harmattan. GUILLAUME, G. (1929), Temps et verbes : théorie des aspects, des modes et des temps, Paris, Champion, 1968.

IZARD, V., PICA, P., DEHAENE, S., HINCHEY, D., SPELKE, E. (2011), “Geometry as a Universal Mental Construction", in Space, Time and Number in the Brain. Searching for the foundations of mathematical thought, S. Dehaene \& E. Brannon eds, Academic Press, London, Elsevier, p. 319-332. 
JACKENDOFF, R. (1991), Semantic Structures, Cambridge, MA, MIT Press.

KNIERIM, J.J. (2007), “The Matrix in your Head”, in The Science of Intuition, Scientific American Mind, vol. 18, n³, www.sciammind.com, p. 42-48.

KRAFT, U. (2007), "Rhythm and Blues", in The Science of Intuition, Scientific American Mind, vol. 18, $\mathrm{n}^{\circ} 3$, www.sciammind.com, p. 62-65.

KREITZER, A. (1997), "Multiple levels of schematization: a study in the conceptualization of space”, in Cognitive Linguistics, 8(4), p. 291-325.

LAKOFF, G., JOHNSON, M. (1980), Metaphors We Live By, Chicago, The University of Chicago Press.

LAKOFF, G. (1987), Women, Fire and dangerous Things: What Categories Reveal About the Mind, Chicago, The University of Chicago Press.

LANGACKER, R. (1991), Concept, Image, and Symbol: The Cognitive Basis of Grammar, Berlin, New York, Mouton de Gruyter.

LAPAIRE, J.-R. (1994), “Le cas Lakoff”, in Modèle linguistiques, tome XV, Fascicule 1, Lille, Ecole Nationale Supérieure d'Arts et Métiers, p. 99-118.

MERAT, M.-C. (2008a), “Notre passé invente notre futur”, in Science \& Vie, n 1089, p. 62-66.

MERLEAU-PONTY, M (1945), Phénoménologie de la perception, Collection Tell, Paris, Gallimard, 1992.

MERLEAU-PONTY, M (1985), L'œil et l'esprit, Essai, Paris, Folio, 1991.

MOELLER, I. (2007) , “Just a bit different", in American Reports, Special Edition on Child Development, www.sciammind.com,p. 42-47.

PAILLARD, J. (1991b), "Knowing where and how to get there", in Brain and Space, J. Paillard (ed.), Oxford, Oxford University Press, p. 461-481.

PERSEC, S., BURGUE, J.-C. (1999), Grammaire raisonnée 2, Paris, Ophrys.

POINCARE, H. (1908), Science et méthode, Paris, Kimé, 2000.

POTTIER, B. (1992), Sémantique générale, Collection Linguistique Nouvelle, Paris, PUF.

QUIRK, R., GREENBAUM, S., LEECH, G., SVARTVIK, J. (1995), A Comprehensive Grammar of the English Language, London, Longman.

RICE, S. (1996), "Prepositional prototypes", in The construal of space in language and thought, M. Pütz \& R. Dirven (éd.), Berlin, Walter de Gruyter, p. 135-165.

RICE, S., SANDRA, D., VANRESPAILLE, M. (1999), "Prepositional semantics and the fragile link between space and time", In Cultural, Psychological and Typological Issues in Cognitive Linguistics: Selected Papers of the Bi-annual ICLA Meeting in Albuquerque, July 1995, M. Hiraga, Chris Sinha, and Sherman Wilcox (eds.), Philadelphia, John Benjamins, p. 108-127.

RIZZOLATI, G., SINIGAGLIA, C. (2008), Les neurones miroirs, Paris, Odile Jacob.

ROUSSEAU, A. (2010), “La problématique du temps. Réflexions méthodologiques à partir des paramètres des langues naturelles", in Système et chronologie, Collection Rivages linguistiques, sous la direction de Catherine Douay, Rennes, Presses Universitaires de Rennes, p. 17-39.

ROUSSEL, E. (2007b) : "Point de vue neurolinguistique sur des réalisations linguistiques", in Anglophonia/Sigma n²2/2007, Université de Toulouse-Le Mirail, Presses Universitaires du Mirail, Toulouse, p. 161-178. 
ROUSSEL, E. (2012b) : "Limits, space and the preposition over", submitted for publication. SANDRA, D., RICE, S. (1995), "Network analyses of prepositional meaning: mirroring whose mind - the linguist's or the language user's?", in Cognitive Linguistics 6(1), pp. 89-130.

SÖDERLIND, J. (1960), “On the preposition over”, in English Studies, Vol. XLI, Nº 5, p. 297-305. SPELKE, E.S. (2011), "Natural Number and Natural Geometry", in Space, Time and Number in the Brain. Searching for the foundations of mathematical thought, S. Dehaene \& E. Brannon eds, Academic Press, London, Elsevier, p. 287-317.

SWEETSER, E., NUNEZ, R., (2006), "With the Future Behind Them: Convergent Evidence From Aymara Language and Gesture in the Crosslinguistic Comparison of Spatial Construals of Time", in Cognitive Science vol. 30, N. 3, Cognitive Science Society, p. 401-450.

TALMY, L. (2000), Toward a Cognitive Semantics (2 vol.), Cambridge, MA, MIT Press

TYLER, A.., EVANS, V. (2001), "Reconsidering prepositional polysemy networks: the case of over". Language, Vol. 77, No. 4, p. 724-765 (http://www.vyvevans.net/over.pdf).

TYLER, A., EVANS, V. (2003), The Semantics of English Prepositions. Spatial scenes, embodied meaning and cognition, Cambridge, Cambridge University Press.

Ullman, M.T. (2006), "Language and the Brain", in An Introduction to Language and Linguistics, Cambridge, Cambridge University Press, p. 235-273.

VANDELOISE, C. (1986), L'espace en français : sémantique des prépositions spatiales, Paris, Seuil.

VANDELOISE, C. (1990), "Representation, prototypes, and centrality”, in Meanings and Prototypes: Studies in Linguistic Categorization, Savas L. Tsohatzidis (ed.), London and New York, Routledge, p. 403-437.

VANDELOISE, C. (2001), Aristote et le lexique de l'espace : rencontres entre la physique grecque et la linguistique cognitive, Stanford, CA, CSLI.

VINCENT, J.-D., (2007), Voyage extraordinaire au centre du cerveau, Paris, Odile Jacob.

WRIGHT, K. (2006), “Times of our Lives”, in A Matter of Time, Scientific American, vol. 16, n¹, www.sciam.com, p. 26-33.

Corpus :

ADAMCZEWSKI, H., GABILAN, J.-P., (1996), Déchiffrer la grammaire anglaise, Paris, Didier.

AŠIĆ, T. (2008), « Espace, temps, prépositions ", in Langues et cultures, Vol. 41, Genève-Paris, Librairie Droz.

British National Corpus, http://www.natcorp.ox.ac.uk/ (BNC)

BROOKNER, A. (1993), Hotel du Lac, London, Penguin.

DESAI, K. (2006), The Inheritance of Loss, London, Penguin.

FORTSON, B. W. (2004), Indo-European Language and Culture. An Introduction. Second Edition. Blackwell Textbooks in Linguistics, 19, Oxford, Chichester, Wiley-Blackwell, 2010

HELLER, J. (1961), Catch-22, New York, Simon \&Schuster

KENT, C. (2005), The Summer House, London, Penguin.

LAURIE, H. (1996), The Gun Seller, London, Arrow Books, 2004.

LESSING, D. (1989), The Grass is Singing, London, Paladin. 
MOELLER, I. (2007), "Just a bit different", in American Reports, Special Edition on Child Development, www.sciammind.com,p. 42-47.

Oxford Advanced Learners' Dictionary (2005), 7th edition, Oxford, Oxford University Press (+ CDROM).

RENDELL, R. (2003), The Babes in the Wood, London, Arrow Books.

RENDELL, R. (2004), The Rottweiler, London, Arrow Books.

ROTHENBERGER, A., BANASCHEWSKI, T. (2007) : "Informing the ADHD Debate”, in The Early Years. From Baby to Teen: How a Child's Mind grows, Scientific American Reports, Special Edition on Child Development, www.sciammind.com, p. 36-41.

SWIFT, G. (1997), Last Orders, New York, Vintage.

Le Petit Robert (2002), Paris, Dictionnaires Le Robert.

Longman Dictionary of English Language and Culture (1998), Harlow, Longman Ltd.

Macmillan English Dictionary for Advanced Learners (2006), Oxford, Macmillan.

\section{NOTES}

1. In $A$ over $B$ sequences where $A$ stands for a noun phrase or a verb and $B$ stands for a noun phrase, such as NP over NP or V over NP.

2. "Following the example of numerous critics, the present account will favour an opposite reading and will suggest that linguistic diversity is nothing but the reflection of the conceptual richness that enables man to grasp/understand his surroundings. Using recent arguments based on well-known facts in today cognitive linguistics, I will point out that the richness in question could in fact be at the cognitive root of the development of languages. [...] Eventually, since my thought cannot but be interdisciplinary, my discussion will follow the recent questions raised by cognitive science in the history of language and mankind." The translation is ours.

3. "... which is naturally visible. The subject perceives something through the sense of sight."

4. The "notional" values in question can also be defined as "abstract" or "thematic" values.

5. We do not mention immobility, which we could do in theory, since we have just seen that this is a concept which does not exist in space.

6. E. Roussel (2012b) for the complete paper.

7. The sense of sight is not the only sense involved.

8. It is in connection with our body that we locate external objects, and the only space relationships that we can imagine are the relationships of these objects to our body."

9. That is, the analysis of their various components of meaning.

10. See E. Roussel (2012b) for a detailed discussion of these occurrences.

11. We would like to thank one of our reviewers for pointing out to us that the presence of all (all over) is synonymous with random multidirectionality.

12. Here is another interesting example, noted once our study was over: "Even when gestures are symbolic, they go little beyond the obvious, as when one points back over one's shoulders to indicate past time" (Bloomfield 1935: 39).

13. "Head", "tip".

14. "Ridge".

15. Belonging to the four elements.

16. The sign + indicates that the semantic feature is present. 
17. That is to say the recapitulation in ego, which is the cognitive source necessary to the analysis.

18. Whereas the following utterances are correct when on is used instead of over: (27) Equally, if we see that the electricity industry is not performing to maximum efficiency and should be doing better there is general agreement on that - surely we have an obligation to do something about it. (BNC, HHX 16809); (28) The results of the research should demonstrate how effective such tripartite training bodies are in fostering agreement on the training needs of the sectors concerned and in acting upon these needs. (BNC, HJ2 3909) ; (29) As US agreement on inter-nationalization was considered unlikely, Britain would also prepare to operate in a Europe- or Commonwealth-centred system. (BNC, A6G 458) ; (30) Both sides shall give real substance to the agreement on the creation and work of cultural centres and fully exploit them. (BNC, HLO 4460).

19. We thank I. Haïk for this remark.

20. In other words, the referent of A cannot entail a stabilized relation, as one of our reviewers suggested, because it necessarily denotes a bipolar situation. Agreement on the other hand names a resolved situation, and as such cannot be used with over. This may explain why agreement is correct with on, and suggests that on is compatible with stabilization.

21. A relation in which the first term is in fact $B$, not A: [B (cause) - A (effect)]. When over intervenes, it reverses the initial order and we obtain: [A (effect) - B (cause)].

22. Duration is usually defined as the period of time that has elapsed between two observed limits: the initial limit and the final limit.

23. The same is true for the day, the week or the month. Interestingly enough, the year that is implicitly referred to is almost exclusively the calendar year, without it being necessarily specified. Accordingly, there doesn't seem to be any need for the definition of what the word year denotes.

24. "During situe dans le temps." (Persec \& Burgué 1999: 30)

25. "[Over] indique la durée d'un état ou d'une action jusqu'au moment présent." (Persec \& Burgué 1999: 36)

26. "[Le present perfect] établit un lien avec le présent." (Persec \& Burgué 1999: 36)

27. All the more so when dealing with time and space.

28. Episodic memory, together with semantic memory, which is totally independent from the space-time context of its acquisition and concerns lexical competence, is part of declarative memory, which is one of the two sub-systems in our long-term memory. The declarative memory system is conscious and its contents can be transmitted. The other long-term memory subsystem is procedural memory; it is not conscious and deals with automatic skills.

29. The atomic second is the time necessary for a ray of light to do 9192631770 oscillations.

30. "Partie subjective du temps physique."

31. One can notice that the contrast between subjective time (or duration) and objective time does not fall within the sole competence of modern philosophy for which duration corresponds to lived time: "The duration lived by our conscience is duration whose specific rhythm is quite different from the time dealt with by the physicist - La durée vécue par notre conscience est une durée au rythme déterminé, bien différente de ce temps dont parle le physicien" (Bergson 1889). We would like to thank one of our reviewers for mentioning that element. Yet, we can notice that the conscience mentioned by Bergson has more to do with memory and that it builds up on our experience. One can also refer to M. Merleau-Ponty to have an interesting definition of perception which would be "the background against which all the acts would stand out and it would be presupposed by them - le fond sur lequel tous les actes se détachent et elle est présupposée par eux." (1945, II) Would not that be another way of saying that things are perceived only because they can be perceived (cf. supra the properties of A and B in their spatial use)?

32. It is noteworthy that the word "moment" is etymologically linked to "movement" (as well as to "emotion"...). The Latin word mōmentum, from *movimentum, English "moment", meant 
"movement". French for instance only kept the temporal meaning, that is to say "the time taken by a movement".

33. Things have changed a lot over the last ten years.

34. We would like to thank our informant for pointing out to us that the expression may also be somewhat euphemistic in so far as it prevents the speaker from committing herself to marking all the papers. The example is prospective when the other occurrences of our corpus are retrospective. The preposition seems to imply different notions according to the time reference involved. Accordingly planification, which is part and parcel of time, is either considered as complete (past) or in process (future), as one of our reviewers suggested.

35. Even if B can be dated.

36. "At the weekend": 708 occurrences in the BNC, often specified as in the following example: "EUROPEAN Community leaders will move quickly this week to reassure the Soviet Union that their support for the future 'unity' of the German people at the weekend EC summit is conditional on the maintenance of peace and stability in Europe" (BNC, A9 N91).

37. We can see that here the speaker makes the weekend "last" 48 hours; the listener may well understand the same weekend as fitting the two-day interval denoted by Saturday and Sunday. But for some people a weekend may begin on the Friday (evening). All such dating is subjective.

38. The number of occurrences comprises those constructed on the sequence [during the weekend + date or SP] like (59), (60) and (61).

39. We would like to thank one of our reviewers for bringing Buser and Debru's (2011) book to our attention. As far as the time issue is concerned when time is connected with philosophy, physics or neuroscience, one can also refer, among others, to Bellanger (2008: 45-63), Boroditsky (2011: 333-341), Buzsáki 2005, Damazio (2006: 34-41), Davies (2006: 6-11), Izard et al. (2011: 319-332), Desmarais et al. 1997, Knierim (2007: 42-48), Kraft (2007: 62-65), Mérat (2008: 62-66), Merleau-Ponty 1945, 1985, Rousseau (2010: 17-39), Spelke (2011: 287-317), Sweetser \& Nunez (2006: 401-450), Ullman (2006: 235-273), Vincent 2007, Wright 2006.

40. We have mentioned supra that space defines itself first and foremost from ego (H. Poincaré 1908, 55). The reader can also refer to Buzsáki 2005, Moser in Knierim 2007 or Rizzolati \& Sinigaglia (2008: 78) : "The spatial position of an object [...] is not determined once and for all, so much so that the space it describes must not be understood as static but dynamic." (underlined in the text) [ "La position spatiale d'un objet (...) n'est pas définie une fois pour toutes, de sorte que l'espace qu'elle décrit doit être conçu non pas d'une façon statique, mais sous une forme dynamique. ") ( Souligné dans le texte)]

\section{RÉSUMÉS}

L'article développe une analyse des valeurs thématique (notionnelle) et temporelle de la préposition over dans une perspective qui privilégie un rapport du langage au réel. Un rôle prépondérant est ainsi attribué au phénomène de la perception qui apparaît comme facteur central de la problématique de la préposition dans ces deux emplois spécifiques, comme tel est le cas lorsque le cadre d'emploi de over est spatial. Ce phénomène perceptif est ensuite réinvesti dans la langue en termes d'aspect.

The goal of this study is to define the semantics attached to the notional and "temporal" uses of the preposition over from a viewpoint based on the assumption that language bears some 
relation to the external world. Perception is then shown to have a dominating role, as is the case when over is used in spatial contexts, and to correspond to aspectual factors linguistically.

INDEX

Keywords : over, aspect, duration, notion, perception, physics, sight, space, time

Mots-clés : aspect, over, durée, espace, notion, perception, physique, temps, vue

\section{AUTEUR}

\section{EMMANUELLE ROUSSEL}

Université de Caen Basse-Normandie CRISCO (EA 4255) 